\title{
Chemical Composition and Antimicrobial Activity in Cold Press Oil of Fennel, Anise, White and Black Mustard Seeds
}

\author{
Çağrı Olgun1, Osman Emre Özkan', Betül Güney², Esma Sena Pattabanoglu³, Kerim Güney³, Mahmut \\ Gür ${ }^{1}$
}

${ }^{1}$ Department of Forest Industrial Engineering, Faculty of Forestry, Kastamonu University, TURKEY ${ }^{2}$ Graduate School of Natural and Applied Sciences, Department of Biology, Ankara University, TURKEY

${ }^{3}$ Department of Forest Engineering, Faculty of Forestry, Kastamonu University, TURKEY

\begin{abstract}
In this study, the cold press oil components and antimicrobial activities of fennel (Foeniculum vulgare) and anise (Pimpinella anisum) and white mustard (Sinapis alba) and black mustard (Brassica nigra) species seeds, which are widely used by the people for alternative medicine, were determined. F. vulgare, $P$. anisum, $S$. alba and $B$. nigra species seeds were obtained from cultivated areas in central Anatolia in Turkey. The oil was extracted by using a screw press (MP-001 Cold Press, Turkey), and the volatile oil components and fatty acid components in these oils were analysed by GCMS and total phenolic content, total flavonoid content and antioxidant activities by DPPH and FRAP (\%) method were determined. Antimicrobial activities of obtained oils were investigated by using minimum inhibitory concentration (MIC) test by against 18 different species microorganisms. In the GCMS results, $F$. vulgare and $P$. anisum oils were found to be the most abundant components which were anethole $(89.74 \%, 88.95 \%$, respectively). According to these results, the plants oils didn't show any antimicrobial activities against tested microorganisms. However especially white and black mustard oils showed strong antioxidant activity when compared with artificial antioxidants.
\end{abstract}

Keywords: Cold Press Oils, Gs-Mc, Antioxidant Activity and Antimicrobial Activities.

\section{INTRODUCTION}

The medicinal using of non-wood forest products have become widespread with the development of alternative medicine as complementary to modern medicine. These plants can be easily purchasable as a product of volatile oils, cold press oils, solvents extracts, or dry tea. However, it is a fact that their components adversely affecting people during the use of these products depending on their amounts. ${ }^{1,2}$ On the other hand, if these products, do not show antibacterial properties, are kept for a long time by the end user, they can cause excessive damage due to the contamination of harmful bacteria. Therefore, it is important to determine the contents of these products and know their properties for standardization. ${ }^{2}$
Foeniculum vulgare (fennel) and Pimpinella anisum (anise) are famous and common used plants having the carminative effect. ${ }^{3} 45$ Also, Sinapis alba (white mustard) and Brassica nigra (black mustard) are used as a spice in cooking and are used for diuretic, appetizing, and atrit in alternative medicine. ${ }^{3}$

In this study, oils of F. vulgare, $P$. anisum, $S$. alba and B. nigra seeds were obtained by using cold-press machine. The obtained oils were chemically analysed with GC-MS and tested against 18 microorganism by the Minimum Inhibitory Concentration (MIC) test. Furthermore, it was determined antioxidant activity, total phenolic and total flavonoid contents.
DOI: 10.5530/ijper.51.3s.12 Correspondence: Cağrı OLGUN,

Department of Forest Industrial Engineering, Faculty of Forestry, Kastamonu University, TURKEY

Phone no:+90 3662801714 E-mail: colgun@kastamonu. edu.tr 


\section{MATERIALS AND METHODS}

\section{Plant Samples and Oil Extraction}

$F$. vulgare, $P$. anisum, $S$. alba and B. nigra seeds were obtained from cultivated areas in central Anatolia in Turkey. The cold-press oil of seeds was extracted by using a screw press (MP-001 Cold Press, Turkey). ${ }^{4}$

\section{Determination of Antimicrobial Activities}

Antimicrobial activities were determined by MIC test with a slight modification against the 18 different microorganism. ${ }^{6}$ Oils were sterilized by filtration using $0.45 \mu \mathrm{m}$ filters (Millipore). Two-fold dilutions of the oils were prepared ranging from $100 \mu \mathrm{g} / \mathrm{mL}$ to $0.195 \mu \mathrm{g} / \mathrm{mL}$ by using 96-well micro-titration plate.

\section{GC-MS Analysis}

Samples was analysed by GCMS QP 2010 Ultra (Shimadzu) equipped with Rtx-5MS capillary column $(30 \mathrm{~m} \cdot 0.25 \mathrm{~mm}$; coating thickness $0.25 \mu \mathrm{m}$ ). For the identification of chemical components, both fatty acid and essential oil Wiley Data library were used. Experimental conditions were applied according to Wiley Data library matching requirements.

\section{Determination of Total Phenolic Content, Total Flavonoid Content and Antioxidant Activities}

Total Phenolic Content and Total Flavonoid Components were determined according to literature studies with slight modifications. ${ }^{5-7,8}$ The total phenolic contents were calculated as micrograms of gallic acid equivalent (GAE) obtained from standard gallic acid graph $\left(\mathrm{R}^{2}=0.9965\right)$ and the total flavonoid contents were calculated as micrograms of catechin equivalent obtained from standard catechin graph $\left(\mathrm{R}^{2}=0.9965\right)$. Antioxidant activities of cold press oils were determined by FRAP (\%,) and DPPH (\%) methods. For this purpose, $10 \%$ oil- methanol solution were prepared and tested according to literature studies with slight modifications. ${ }^{5-9,10}$

\section{RESULTS AND DISCUSSION}

The components, which observed more than 3 percent, were accepted as the main components in the oils. GC-MS results were scanned in both the essential oil and fatty acid database, and their main components are shown in Table 1 and 2. The MIC test results of oils are given in Table 3. The most abundant component of the fennel and anise oils to according to essential oil database is similar comparison with previous studies. ${ }^{11,12}$ It was seen that methyl linoleate is also a common component of the four cold-press oils according to results of fatty acid database scanning. However, it was found that essential oils of these species had antimicrobial activity in the previous studies, but any antimicrobial activities weren't observed in cold press oils in this study. ${ }^{11,12,13,14 .}$

\begin{tabular}{|c|c|c|c|c|c|c|c|}
\hline \multicolumn{7}{|c|}{ Table 1: Main components in essential oil scanning } \\
\hline White Mustard & $\%$ & Black Mustard & $\%$ & Anise & $\%$ & Fennel & $\%$ \\
\hline $\begin{array}{c}\text { Cyclopropanenonanoic } \\
\text { acid, 2-[(2-butylcyclopropyl) } \\
\text { methyl]-, methyl ester }\end{array}$ & 48.7 & $\begin{array}{c}\text { Di-(9-Octadecenoyl)- } \\
\text { Glycerol }\end{array}$ & 42.16 & Anethole & 89.74 & Anethole & 88.95 \\
\hline $\begin{array}{c}\text { Hexadecanoic acid, } \\
\text {-(hydroxymethyl)-1,2- } \\
\text { ethanediyl ester }\end{array}$ & 42.08 & $\begin{array}{c}\text { 9,12-octadecadienoyl } \\
\text { chloride, (Z,Z)- }\end{array}$ & $\begin{array}{c}\text { Butanoic acid, } \\
\text { 2-methyl-, } \\
\text { 2-methoxy-4-(2- } \\
\text { propenyl)phenyl ester }\end{array}$ & 3.19 & D-Limonene & 3.41 \\
\hline & $\begin{array}{c}\text { Hexadecanoic acid, } \\
\text { 1-(hydroxymethyl)-1,2- } \\
\text { ethanediyl ester }\end{array}$ & 13.2 & & & \\
\hline
\end{tabular}

\begin{tabular}{|c|c|c|c|c|c|c|c|}
\hline \multicolumn{7}{|c|}{ Table 2: Main components in fatty acid scanning } \\
\hline W. Mustard & $\%$ & B. Mustard & $\%$ & Anise & $\%$ & Fennel \\
\hline Methyl linoleate & 68.19 & Methyl erucate & 38.23 & Methyl elaidate & 60.44 & Methyl elaidate & 66.44 \\
\hline Methyl oleate & 15.79 & $\begin{array}{c}8,11,14-\text {-Docosatrienoic } \\
\text { acid, methyl ester }\end{array}$ & 23.72 & Methyl linoleate & 20.01 & Anethole & 14.18 \\
\hline $\begin{array}{c}\text { Hexadecanoic acid, } \\
\text { methyl ester }\end{array}$ & 10.51 & $\begin{array}{c}11 \text {-Eicosenoic acid, } \\
\text { methyl ester }\end{array}$ & 15.82 & Anethole & 10.84 & Methyl linoleate & 10.28 \\
\hline & Methyl linoleate & 10.13 & $\begin{array}{c}\text { Hexadecanoic } \\
\text { acid, methyl ester }\end{array}$ & 3.7 & $\begin{array}{c}\text { Hexadecanoic } \\
\text { acid, methyl ester }\end{array}$ & 3.88 \\
\hline
\end{tabular}




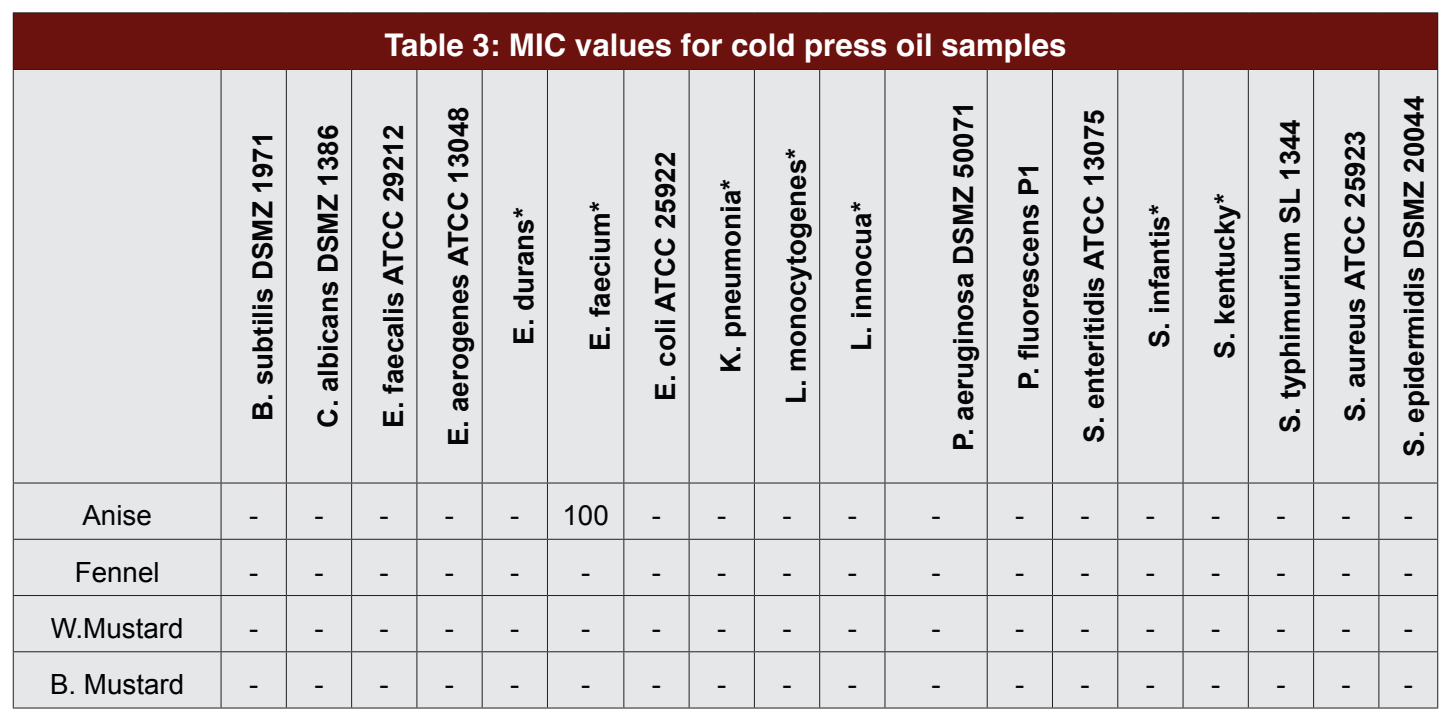

"-": No inhibition observed for the volumes of oils tested

* Isolated from food samples and identified at the Department of Biology, Faculty of Science, and Ankara University.

\begin{tabular}{|ccccc|}
\hline \multicolumn{5}{c}{ Table 4: Total Phenolic Contents and Total Flavonoid Contents } \\
\hline GAE/ML & W. Mustard & B. Mustard & Anise & Fennel \\
Total Phenolic & 167,78 & 142,86 & 480,62 & 333,21 \\
Total Flavonoid & 12,09 & 23,43 & 16,47 & 17,8 \\
\hline
\end{tabular}

\begin{tabular}{|ccccccccc|}
\hline \multicolumn{1}{c|}{ Table 5: Antioxidant activities of cold pressed oils } \\
\hline Method & B. Mustard & W. Mustard & Fennel & Anise & BHA & BHT & TOC \\
Frap (\%) & 23,85 & 8,92 & 0,64 & 3,12 & 10,66 & 2,51 & 2,76 \\
DPPH (\%) & 89,25 & 94,24 & 39,64 & 45,34 & 94,17 & 88,73 & 77,46 \\
\hline
\end{tabular}

The total phenolic contents and total flavonoid contents of cold-press oils are given in Table 4. Besides, antioxidant activities results of cold-press oils are given in Table 5. The highest total phenolic content was found in anise oil, and also, the maximum total flavonoid amount was found in black mustard oil. On the other hand, black and white mustard oils exhibited very strong antioxidant activities in comparison to artificial antioxidant while anise and fennel showed low antioxidant activities. Ghanem et al. reported that different solvent extractives of fennel showed high antioxidant activities. ${ }^{5}$ For this reason, it will be said that non-antioxidant materials are obtained in cold press oil extraction process.

\section{CONCLUSION}

It can be clearly said that F. vulgare and P. anisum have significant potential as raw material to obtain high quality anethole for pharmaceutical industry. Fennel, anise, white and black mustard cold press oils have rather high total phenolic content, and also, white and black mustard cold press oils have strong antioxidant activities. Besides, it may be recommended that these cold press oils are used with the purpose of increasing the shelf-stable of food and medicines due to their preservative properties against microorganisms.

\section{ACKNOWLEDGEMENT}

The authors are thankful to Kastamonu University for providing research facility

\section{CONFLICT OF INTEREST}

None

\section{ABBREVIATION USED}

GC-MS: Gas chromatography-mass spectrometry; W. Mustard: White Mustard; B. Mustard: Black Mustard; DSMZ: German Collection of Microorganisms and Cell Cultures; ATCC: American Type Culture Collection; ID: Identity; MIC: Minimum Inhibitory Concentration; GAE/ML. gallic acid equivalence/milliliters; 
FRAP: The Ferric Reducing Ability of Plasma; DPPH: 2,2-Diphenyl-1-picrylhydrazyl.

\section{REFERENCES}

1. Erdem S, Ata Eren P. Adverse effects of herbal medicines and products. Türk Hijyen ve Deneysel Biyoloji Dergisi. 2009;66(3):133-41.

2. Faydaoğlu E, Sürücüoğlu MS. History of the use of medical and aromatic plants and their economic importance. Kastamonu Üniversitesi Orman Fakültesi Dergisi. 2011;11(1):52-67.

3. Khan IA; Abourashed EA. Leung's encyclopedia of common natural ingredients: used in food, drugs and cosmetics. John Wiley \& Sons; 2011.

4. Prasad R, Lawania RD, Gupta R. "Role of herbs in the management of asthma." Pharmacognosy Reviews. 2009;3(6):247-57.

5. Ghanem MT, Radwan HM, Mahdy ESM, Elkholy YM, Hassanein HD, Shahat AA. Phenolic compounds from Foeniculum vulgare (Subsp. Piperitum) (Apiaceae) herb and evaluation of hepatoprotective antioxidant activity. Pharmacognosy research. 2012;4(2):104-8.

6. Balouiri M, Sadiki M, Ibnsouda SK. Methods for in vitro evaluating antimicrobial activity: A review. Journal of Pharmaceutical Analysis. 2016;6(2):71-9.

7. Ateş S, Gür M, Özkan OE, Akça M, Olgun Ç, Güder A. Chemical Contents and Antifungal Activity of Some Durable Wood Extractives vs. Pleurotus ostreatus. BioResources. 2015;10(2):2433-43.
8. Tian S, Shi Y, Zhou X, Ge L, Upur H. Total polyphenolic (flavonoids) content and antioxidant capacity of different Ziziphora clinopodioides Lam. Extracts. Pharmacognosy magazine. 2011;7(25):65-9.

9. Ozkan OE, Zengin G, Akca M, Baloglu MC, Olgun C, Altuner EM, et al. DNA protection, antioxidant, antibacterial and enzyme inhibition activities of heartwood and sapwood extracts from juniper and olive woods. RSC Advances. 2015;5(89):72950-8.

10. Khan A, Anand V, Badrinarayanan V, Thirunethiran K, Natarajan P. In vitro Antioxidant and Cytotoxicity Analysis of Leaves of Ficus racemosa. Free Radicals and Antioxidants. 2017;7(1): 8-12.

11. Shahat AA, Ibrahim AY, Hendawy SF, Omer EA, Hammouda FM, AbdelRahman $\mathrm{FH}$, et al. Chemical composition, antimicrobial and antioxidant activities of essential oils from organically cultivated fennel cultivars. Molecules. 2011;16(2):1366-77

12. Acimovic M, Tesevic V, Todosijevic M, Djisalov J, Oljaca S. 2015. Compositional characteristics of the essential oil of Pimpinella anisum and Foeniculum vulgare grown in Serbia. Botanica Serbica. 2015;39(1):9-14.

13. Bhatia M, Sharma A. Inhibitory activities of Brassica nigra, Cinnamomum cassia (Blume) and Cuminum cyminum towards Escherichia coli and Staphylococcus aureus. Applied Science Research. 2012;4(4):1811-5

14. Jain N, Meenakshi S. Insignificant antidermatophytic activity of Brassica campestris oil. Journal of Pharmaceutical Negative Results. 2014;5(1):22-4.

\section{PICTORIAL ABSTRACT}

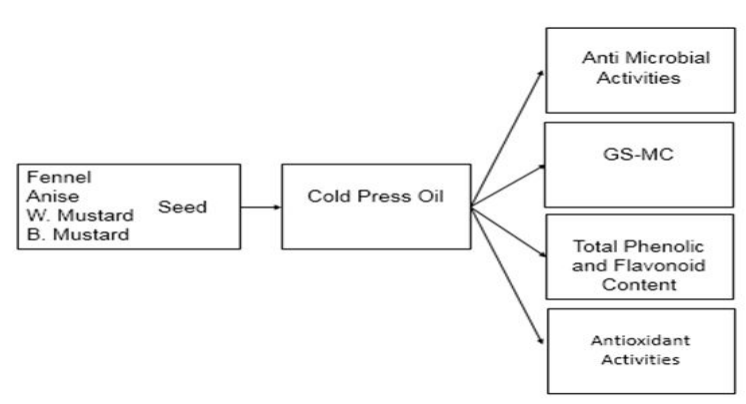

\section{SUMMARY}

- Antimicrobial activities of the fennel, anise, white and black mustard cold pressed oils were investigated by using MIC test by against 18 different species microorganisms.

- The chemical components of the cold pressed oils were determined with GC-MS.

- Total phenolic, total flavonoid and anti-oxidant activities of oil samples were investigated.

\section{ABOUT AUTHORS}

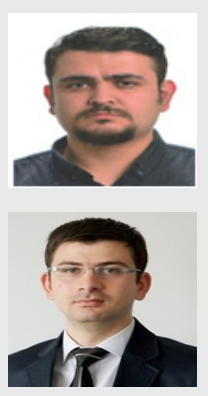

Çağrı Olgun is working as a research assistant in Forest Industry Engineering Department, Faculty of Forestry in Kastamonu University, TURKEY. Research interests include fiberboard, wood chemistry and non-wood forest product industry.

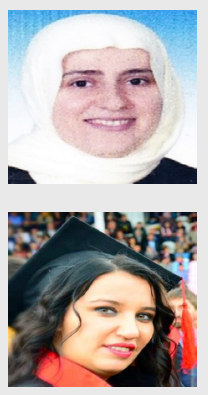

Betül Güney completed her Master in Graduate School of Natural and Applied Sciences of Ankara University (Biology) in 2005. She continues her Doctorate in same department. She has many publications on flora and vegetation.

Osman Emre Özkan is working as a research assistant in Forest Industry Engineering Department, Faculty of Forestry in Kastamonu University, TURKEY. Research interests include non-wood forest product and its biological activity.

Esma Sena Pattabanoğlu completed graduation in 2015 at Kastamonu University Faculty of Forestry Department of Forestry Engineering. She continues her M.Sc. education in the same department. 
Kerim Güney has been working as Assistant Professor at Botanic department, Forest Engineering Faculty in Kastamonu University. Kerim Güney has many publications on flora, vegetation, biodiversity and medical and aromatic plants.

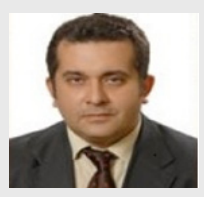

Mahmut Gür has been working as Assistant Professor in Kastamonu University at Forest Industrial Engineering department, Kastamonu. He is interesting in the development of synthetic molecules. He has published several publications in different journals in National and International Repute.

Cite this article: Olgun Ç, Özkan OE, Güney B, Pattabanoglu ES, Güney K, Gür M. Chemical Composition and Antimicrobial Activity in Cold Press Oil of Fennel, Anise, White and Black Mustard Seeds. Indian J of Pharmaceutical Education and Research. 2017;51(3)Suppl:S200-04. 